\title{
Dead Wood: Key to Enhancing Wildlife Diversity in Forests $^{1}$
}

Holly K. Ober and Patrick J. Minogue 2

Animals require specific habitat elements to satisfy their basic needs of food, water, and cover. Although landowners interested in enhancing forest habitat for wildlife often consider the species and age of live vegetation, they often overlook the importance of dead wood. Dead wood provides resources for many different species of animals. In fact, for some forest wildlife, wood only becomes valuable after death.

Three forms of dead wood provide important resources for wildlife: standing dead trees (snags), large diameter dead wood that has fallen to the ground (logs; also called "coarse woody debris"), and smaller diameter branches and twigs gathered into a mound (a brush pile). Each of these forms of dead wood provides unique habitat features for wildlife.

\section{Snags}

Cavities within trees are required by many wild animals. Nearly 40 species of birds in Florida nest in tree cavities, including red-cockaded woodpeckers, hairy woodpeckers, downy woodpeckers, pileated woodpeckers, southeastern American kestrels, screech owls, brown creepers, brown-headed nuthatches, white-breasted nuthatches, eastern bluebirds, Carolina chickadees, and Carolina wrens. Many mammals use tree cavities as well, including evening bats, big brown bats, Rafinesques big-eared bats, squirrels, raccoons, opossums, and bears.

Different kinds of trees develop cavities at different ages. In hardwood trees (deciduous, broadleaved trees, such as oaks, maples, and elms), cavities often form while trees are alive. In conifers (cone-bearing, softwood trees, such as pines and cypress), cavities are more likely to form after trees die. For this reason, natural deciduous forests tend to have many more cavities than conifer stands.

Intensively managed conifer plantations are often grown on short rotations to maximize financial returns. In these stands, very few live trees have cavities, and snags are usually removed to provide space for growing trees. Therefore, habitat for all those wildlife species dependent upon cavities may be absent. In regions where managed conifer stands cover large acreages, the scarcity of cavities may severely limit survival of many wildlife species across these large areas. Increases in the number of

1. This document is WEC 238, one of a series of the Wildlife Ecology and Conservation Department, Florida Cooperative Extension Service, Institute of Food and Agricultural Sciences, University of Florida. Original publication date July 11, 2007. Visit the EDIS Web Site at http://edis.ifas.ufl.edu.

2. Holly K. Ober, assistant professor and Wildlife Extension Specialist, Department of Wildlife Ecology and Conservation; Patrick J. Minogue, assistant professor and Forestry Extension Specialist, School of Forest Resources and Conservation, University of Florida, Institute of Food and Agricultural Sciences, University of Florida, Gainesville, FL 32611.

The Institute of Food and Agricultural Sciences (IFAS) is an Equal Opportunity Institution authorized to provide research, educational information and other services only to individuals and institutions that function with non-discrimination with respect to race, creed, color, religion, age, disability, sex, sexual orientation, marital status, national origin, political opinions or affiliations. U.S. Department of Agriculture, Cooperative Extension Service, University of Florida, IFAS, Florida A. \& M. University Cooperative Extension Program, and Boards of County Commissioners Cooperating. Larry Arrington, Dean 
snags can greatly increase wildlife diversity in these regions.

Only a small number of the wildlife species that use cavities can create them. Examples of such animals, (called "primary cavity excavators"), include woodpeckers, Carolina chickadees, and brown-headed nuthatches. A much larger group of species relies on pre-existing cavities. Examples of animals in this second group, (called "secondary cavity users"), include owls, bats, many songbirds, and many small mammals. In areas where primary excavators, cavity-prone hardwoods, and conifer snags are scarce, artificial nest boxes can provide additional habitat for secondary cavity users. See edis.ifas.edu/UW058 for more information on creating nest boxes for wildlife.

Snags provide more to wildlife than just shelter within cavities (figure 1). Crevices formed between the trunk of a dead tree and the peeling bark provide protection from the sun for bats and amphibians. Branches free of leaves serve as perches for birds of prey to view movements of prey below. Decaying wood is home to many insects and fungi which serve as food for birds, mammals, amphibians, and reptiles.

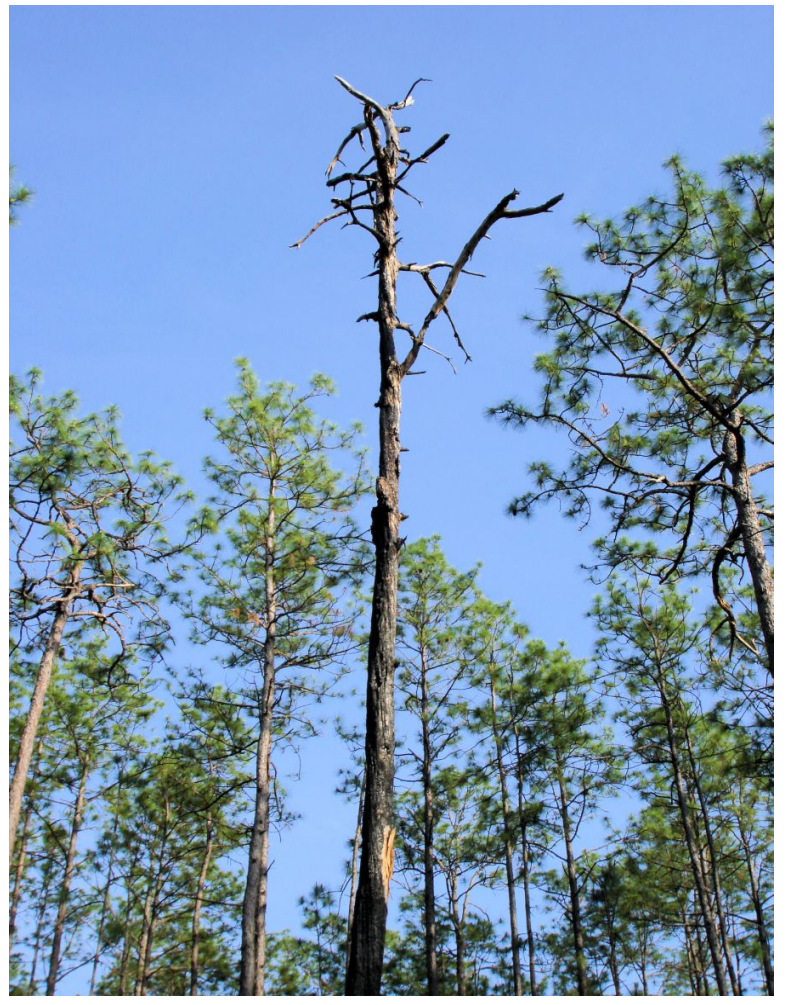

Figure 1. Snags provide shelter, perches, and food resources. Credits: H. K. Ober.

\section{Logs}

Logs are another form of dead wood, useful to an entirely different group of animals. Logs on the forest floor (figure 2) provide shelter for animals of many sizes, such as bear and turkey vultures at the large end of the spectrum, and mice, salamanders, lizards, toads, and frogs at the small end. The high humidity inside and beneath decaying logs offers moist conditions that help wet-skinned amphibians stay wet. The upper sides of logs are used by animals as platforms for basking in the sun. Small mammals such as voles and shrews use the interior of logs as nest sites and as places to hide from predators.

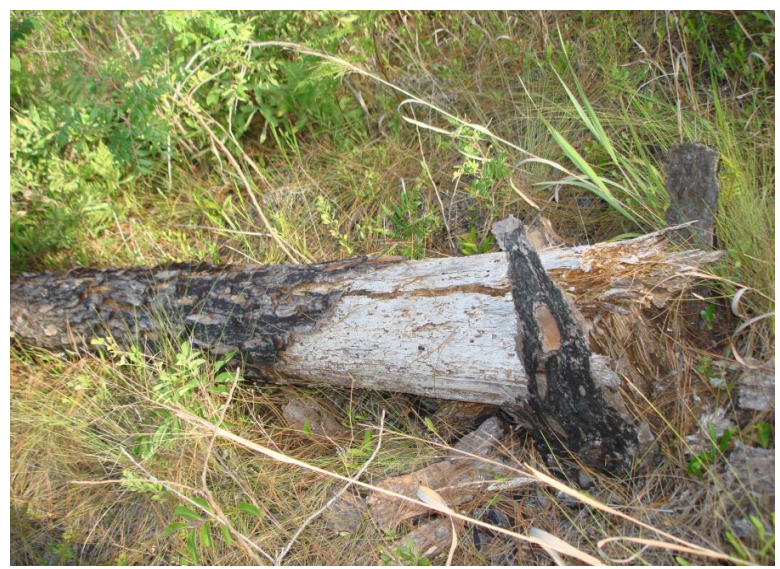

Figure 2. Logs provide shelter, humid microclimate, basking sites, navigational aids, and food resources. Credits: H. K. Ober.

In addition to shelter, logs provide food resources and help animals navigate. The fungi, spiders, beetles, termites, ants, grubs, worms, snails, and slugs found inside rotting logs are food for animals such as salamanders, snakes, birds, mice, shrews, and bears. Logs also provide landmarks, territory markers, and movement pathways across the forest floor for small mammals.

\section{Brush Piles}

Brush piles are mounds of woody vegetation that can be artificially created for the benefit of wildlife (figure 3). The primary function of brush piles is to provide shelter from the weather and from predators. The lower portions of a brush pile provide cool, shaded conditions. These areas can be used as resting sites for amphibians and reptiles and as escape cover for many mammals. The upper layers can be used as 
perch sites and nest sites by songbirds. In managed stands with no understory trees or shrubs, these piles may be the only place for songbirds to build nests.

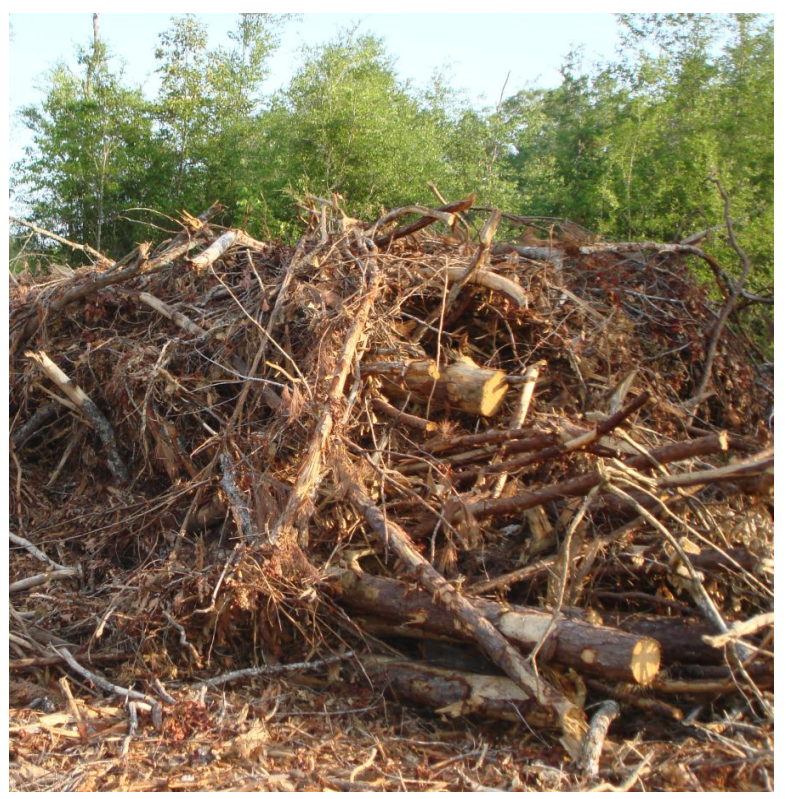

Figure 3. Brush piles provide shelter, shade, perch sites, and food resources. Credits: H. K. Ober.

Brush piles also supply food resources for wildlife. As the material in brush piles decays, insects are attracted. Insect-eating animals will soon follow. As the abundance of smaller animals seeking insects or shelter in a pile increases, predators that feed on these smaller prey will be attracted. Thus, owls, hawks, foxes, and coyotes may ultimately visit brush piles.

\section{How Is Dead Wood Created?}

\section{Snags}

Snags can be created naturally or artificially. Lightning, wind, ice, fire, and accidental logging damage can kill trees instantly. These factors can also weaken trees, increasing the chances of death in the future from disease and insects. Many managed forest landowners remove dead trees because of concerns for safety, fire, and insect outbreaks. When deciding whether or not to allow snags to remain in or near a managed stand, it is necessary to weigh these concerns against the many potential benefits snags can provide for wild animals. In healthy stands, individual trees that are either killed instantly or damaged but not killed can provide excellent habitat for wildlife while posing fairly little risk of epidemic insect outbreak. However, this is not true when such trees are located in stands of stressed trees or in areas where many southern pine bark beetles already exist. Stands of stressed trees can result from planting trees at excessive densities or from planting tree species inappropriate for the growing conditions of the site. In these stands, the risk of epidemic insect outbreaks may increase if newly dead and damaged trees are allowed to remain standing. When deciding whether or not to keep snags in or near managed stands, it is wise to consider the health of the stand. For additional advice on risk factors, contact your local County Cooperative Extension or Division of Forestry office.

If additional snag habitat for wildlife is desired, there are several ways new snags can be created. Three techniques used to create snags are girdling, topping, and injecting. Girdling involves cutting through both the bark and the cambium (the actively growing layer of cells just inside the bark) around the entire tree trunk, near the base. This will prevent movement of nutrients throughout the tree, causing death. The process may take such a long time that the tree may fall before cavities have formed, creating a $\log$ rather than a snag. Topping involves removing the tops of trees with chain saws, guns, or explosives. Finally, snags can be created by injecting live trees with cultures of decay organisms or herbicides near the base of the tree.

Snags are also created through the natural process of suppression (called "suppression mortality"). This process is common in southern pine stands, as the larger, healthier trees shade out smaller, less healthy individuals. Stands planted with 500-800 seedlings per acre may have fewer than 100 trees remaining at maturity, with the rest lost to suppression mortality. A similar process occurs in natural stands. Snags created this way are generally of limited use to wildlife. Because trees with the smallest diameters are most likely to die through suppression, these snags provide habitat for small animals only. Also, the fast decay rate of small diameter snags allows them to provide habitat for wildlife for only a short period of time. Finally, southern pine bark beetle infestations often begin in stressed trees, so allowing suppressed trees to remain as snags is not advisable in stands managed for 
timber production. See edis.ifas.edu/IN333 for more information on the habits of southern pine beetles.

\section{Logs}

Logs are formed naturally when live or dead trees fall. In many intensively managed forests where the main goal is financial returns from timber products, dying trees are harvested before they fall. Therefore, log habitat is usually extremely limited in these areas.

There are several ways log habitat can be created for wildlife. First, a few trees of limited value for timber products can be left on the ground after thinning or harvesting. Second, trees that fall during hurricanes, tornadoes, and ice storms can be left on the ground. Due to the risk of southern pine bark beetle infestation in pockets of injured trees, it is recommended that damaged trees be removed from managed stands when large numbers of trees are affected by storms. However, isolated damaged trees may be felled and left on the ground to provide habitat for wildlife. Once again, the health of the stand surrounding a damaged tree should be considered when deciding whether concern for beetle epidemics outweigh the opportunity to provide habitat for wildlife. Finally, when evidence of southern pine beetles is recognized in a stand, it is recommended that infested trees be felled.

Infestations of southern pine beetles can cause death to many surrounding trees if no action is taken. This is particularly true when trees are stressed by dry weather. In this case, felling those trees that are infested can not only protect the stand from epidemic insect outbreak but also provide log habitat for wildlife.

\section{Brush Piles}

Brush piles can be created by piling branches into a small mound. Piling larger diameter branches closer to the ground and smaller material higher up in the heap will result in openings and pathways at the ground level for small animals to move through. Large stumps of decay-resistant tree species, old fence posts, or pole-sized logs can provide a base layer that lasts a long time. Material in the upper layers should be placed in a criss-cross fashion to make the pile stable. Small trees and branches collected during self-thinning, pruning, or road clearing operations can be used to create the upper layers.

Creating brush piles from material collected during other management activities can reduce the costs of moving or disposing of otherwise unwanted material. For example, piles can be created or restocked with the branches, bark, and other woody debris removed from stands when they are cleaned prior to pine-straw collection. Also, instead of creating a single large pile of tree tops (slash) at a logging deck during thinning operations, tops can be left in numerous smaller piles throughout the stand. However, leaving large amounts of fuel on the ground within stands can increase risk of wildfire, so not all slash should be retained. Also, leaving large amounts of slash in direct contact with live trees is not recommended, due to the potential attraction of engraver beetles (Ips species) to freshly cut slash. See edis.ifas.edu/IN701 for more information on the habits of engraver beetles.

\section{How Much Dead Wood Should Be Provided and Where Should It Be Located?}

Careful consideration of the amount, type, and location of dead wood can greatly increase the usefulness of these resources for wildlife. In general, the greater the number and variety of snags, logs, and brush piles, the greater the abundance and variety of wildlife supported. However, animals require more than one habitat element, so consideration should also be given to the arrangement of habitat elements. Locating food and cover resources within close distance of each other is particularly important for animals with low mobility.

\section{Snags}

Each species of wildlife has distinct preferences for tree species, size, and states of decay. Therefore, stands with snags of a variety of species, sizes, and ages will be used by the greatest number of wildlife species. Small diameter snags are rarely used by cavity nesters, but they may provide food for insect-eating animals. Larger snags provide benefits for longer periods of time than smaller snags because it will take more time for them to decay. 
Leaving some large diameter live trees at the time of harvest (a practice called "green tree retention") provides insurance that large diameter trees are available to become snags and then logs in the future. In stands managed for timber production, trees of low value (such as those with forked tops) are a smart choice for green tree retention. These trees are especially likely to develop cavities. Also, leaving a few large diameter snags when harvesting will ensure that snags are available for wildlife at the beginning of the next rotation. This also helps organisms that can't move (such as lichens and mosses) persist from one rotation to the next. These organisms are important food for some wildlife. Because the number of species a snag provides habitat for increases with age, retaining some snags between rotations ensures quality habitat for many species. An absolute minimum of 3 snags per acre should be maintained. Every 5-10 years, new snags should be created to replace those that have been lost.

The location of snags influences which animals will use them. The territorial nature of some cavity-nesting birds may prevent other birds from using snags located close to a snag already used as a nest site. To increase the chances of snags being used by more than a single pair of cavity-nesting birds, snags should be dispersed rather than clumped in one area. However, because many cavity-nesting birds feed on the larvae of wood-boring insects, they require one snag to nest in and others to forage in. Leaving snags in several small groups may be ideal. Due to their flammable nature, it is advisable not to locate snags near firebreaks where burning snags could pose fire dangers to adjacent stands if they fall.

\section{Logs}

The size, decay class, and number of logs will influence which animals use an area. Larger logs are better than smaller logs because larger logs provide more ground cover and greater connectivity across the forest floor, and they last longer. Also, the number of wildlife species that can use a log increases as the size of a log increases. As previously mentioned with snags, different animals prefer logs in different stages of decay. Therefore, providing many logs of different ages is the best strategy to promote a variety of wildlife species. A minimum of $2 \operatorname{logs}$ per acre, each $>6$ feet long, should be maintained.

\section{Brush Piles}

Brush piles are especially useful in areas with little ground and shrub cover. Location is again important: isolated brush piles will be used less than piles near forest edges, field edges, roads, and water sources. The value of brush piles can be increased if several medium-sized piles (4-8 feet tall and 10 feet in diameter) are created rather than one large pile, and if each pile is placed near other habitat elements important to wildlife. For example, constructing brush piles near wildlife food plots may increase use of both the food plots and the brush piles. Be careful not to locate brush piles close to buildings because they can be flammable. They also may increase nuisance wildlife in the buildings. Also avoid areas where standing water might collect, as many animals may be reluctant to use a damp pile. Because brush piles are composed of dead plant materials, the entire pile will settle over time. New material will periodically need to be added to maintain the pile. Two to four piles per acre are recommended.

\section{Conclusion}

No forest stand can provide quality habitat for all the wildlife species that exist in a given region. However, maintaining habitat elements that provide important functions in the lives of many species can have a big impact on the number of species an area supports. Dead wood is one key habitat element that provides resources for a large number of wildlife species.

As the number of people in the state of Florida increases and the amount of natural forestland decreases, managed forests will play a more important role in providing habitat for wildlife. Some of the most obvious differences between intensively managed single-species, single-aged forests versus natural stands is the scarcity of snags, logs, and structural diversity in managed stands. Increasing the numbers of snags, logs, and brush piles in or around managed forests can greatly increase the diversity of species of wildlife these areas support. 
Providing a variety of sizes, species, and decay classes of snags and logs will maximize the number of species of wildlife whose needs are met. Providing a combination of food and cover resources close to one another will maximize benefits for the greatest number of wildlife species. Strategies should be developed to ensure that snags, logs, and brush piles are present over the long term.

\section{Additional Information}

Eickwort, J. M., Mayfield, A. E., III, and Foltz, J. L. Ips engraver beetles, Ips spp. (Insect: Coleoptera: Curculionidae: Scolytinae). IN701 (IFAS Extension Document). University of Florida. Available at http://edis.ifas.ufl.edu/IN701

Hunter, M. L., Jr. 1999. Maintaining Biodiversity in Managed Ecosystems. Cambridge University Press

Lacki, M. J., Hayes, J. P., and Kurta, A. 2007. Bats in Forests: Conservation and Management. John Hopkins University Press

Meeker, J. R., Dixon, W. N., Foltz, J. L., and Fasulo, T. R. Southern pine beetle, Endrocotonus frontais, Zimmermann (Insect: Coleoptera: Curculionidae: Scolyinae). IN333 (IFAS Extension document). University of Florida. Available at http://edis.ifas.ufl.edu/IN333

Schaefer, J. Helping cavity-nesters in Florida. UW058 (IFAS Extension document). University of Florida. Available at http://edis.ifas.ufl.edu/UW058 